\title{
SYNTHESIS, CHARACTERIZATION, AND MOLECULAR DOCKING ANALYSIS OF PROLINE (PYRROLIDINE 2-CARBOXYLIC ACID) AND PROLINAMIDE (PYRROLIDINE 2-CARBOXYLIC ACID AMIDE) ISOMERS AS BACTERIAL COLLAGENASE INHIBITORS
}

\author{
KAVYA SUNDARARAJU ${ }^{1}$, RAMESH KUMAR CHIDAMBARAM ${ }^{1}$, RADHAKRISHNAN NARAYANASWAMY ${ }^{2,3 *}$
}

${ }^{1}$ Department of Chemistry, Organic Chemistry Lab, Vel Tech Rangarajan Dr. Sagunthala R and D Institute of Science and Technology, Avadi, Chennai, Tamil Nadu, India. ${ }^{2}$ Bio Incubator, Vel Tech Technology Incubator, Vel Tech Rangarajan Dr. Sagunthala R \& D Institute of Science and Technology, Avadi, Chennai, Tamil Nadu, India. ${ }^{3}$ Department of Biotechnology, Vel Tech Rangarajan Dr. Sagunthala R and D Institute of Science and Technology, Avadi, Chennai, Tamil Nadu, India. Email: nrkishnan@gmail.com

Received: 22 September 2018, Revised and Accepted: 26 October 2018

ABSTRACT

Objectives: D-proline is an isomer of L-proline, naturally occurring amino acid. Apart from this, several proline homologs and analogs are available in nature. For instance, hydroxyproline one of proline analog plays a key role in collagen function. Inhibition of collagenase activity plays a significant role in protecting the unbalanced turnover of collagen, caused due to inflammation and photoaging of skin. This prompted us to carry out the study on proline and prolinamide isomers.

Methods: These proline and prolinamide isomers were evaluated on the docking behavior of bacterial collagenase using PatchDock. In addition, molecular physicochemical, drug-likeness, absorption, distribution, metabolism and excretion (ADME) analysis, synthesis, and characterization of four prolinamide isomers were also carried out.

Results: All the four synthesized prolinamide isomers showed $>90 \%$ yield. The molecular physicochemical analysis revealed that proline and prolinamide isomers showed nil violation and complied well with the Lipinski's rule of five. ADME analysis showed that prolinamide isomers predicated to have blood-brain barrier permeability. Docking studies revealed that $\mathrm{D}(S, R)$ prolinamide isomer showed the maximum atomic contact energy $(-115.09 \mathrm{kcal} / \mathrm{mol})$ with that of Clostridium histolyticum collagenase.

Conclusion: Thus, the present study showed the potential of proline and prolinamide isomers as collagenase inhibitors.

Keywords: Molecular docking, Proline, Prolinamide isomers, PatchDock, Clostridium histolyticum collagenase inhibitors.

(c) 2019 The Authors. Published by Innovare Academic Sciences Pvt Ltd. This is an open access article under the CC BY license (http://creativecommons. org/licenses/by/4. 0/) DOI: http://dx.doi.org/10.22159/ajpcr.2019.v12i1.29894

\section{INTRODUCTION}

Proline is the $\alpha$-pyrrolidine substituted amino acid of the protein. It is the only $\alpha$-amino acid of protein which contains secondary amine. D-Proline is an isomer of the naturally occurring amino acid, L-Proline. D-Proline has been found in relatively high abundance in human plasma and saliva [1]. This amino acid might be of bacterial origin, but there is also evidence that this is endogenously produced through amino acid racemase activity [2]. L-Proline is one of the 20 amino acids used in living organisms as the building blocks of proteins. Proline is well known as a classical breaker of both the $\alpha$-helical [3] and $\beta$-sheets structures in proteins and peptides, respectively. It is a non-essential amino acid that is synthesized from glutamic acid and other amino acids. It is an essential component of collagen and is important for the proper functioning of joints and tendons.

Several proline analogs and homologs occur in nature, for instance, trans3-hydroxyproline and trans-4-hydroxyproline shown as constituents of common proteins as a result of the post-translational process, especially in collagen. Similarly, 3- and 4- alkylated derivatives of proline and hydroxyproline as well as other proline analogs with ring restrictions (aziridine-2-carboxylic acid and azetidine-2-carboxylic acid) and ring expansions (pipecolic acid) are reported in natural products [4]. In cosmetic and personal care formulations, proline functions as a fragrance ingredient and as well as hair and skin conditioning agent [5]. Similarly, acyl proline salts functions as moisturizing agent [6] and $N$-Lauroyl proline as a slimming agent [7]. This prompted the present study to be carried out on proline and prolinamide isomers. These proline and prolinamide isomers were evaluated on the docking behavior of collagenase using PatchDock. In addition, molecular physicochemical, drug-likeness, and absorption, distribution, metabolism and excretion (ADME) analyses were also carried out.

\section{MATERIALS AND METHODS}

Materials

L-proline and D-proline (Loba), Boc anhydride (Avra), (R)-(+)Methylbenzylamine and (S)-(-)- methylbenzylamine (Aldrich), dicyclohexylcarbodiimide (DCC) (Avra), triethylamine (Avra), trifluoroacetic acid (Avra), and $N, N^{\prime}$-dimethylaminopyridine (DMAP) are commercially available and used without any further purification.

\section{Synthesis of prolinamide}

To a stirred solution of triethylamine $(5 \mathrm{mmol}, 0.7 \mathrm{ml})$ in DCM was added Proline, $1 \mathrm{a}-\mathrm{b}$ ( $4.35 \mathrm{mmol}, 0.5 \mathrm{~g}$ ) and boc anhydride $(6.42 \mathrm{mmol}$, $1.47 \mathrm{ml}$ ). The solution was stirred at room temperature for $1 \mathrm{~h}$. The white cloudy liquid turned colorless. The organic phase was washed with $(3 \mathrm{ml})$ saturated citric acid aqueous solution and $(4 \mathrm{ml} \times 2)$ saturated $\mathrm{NaCl}$ aqueous solution and water. The organic phase was dried over $\mathrm{Na}_{2} \mathrm{SO}_{4}$, evaporated under vacuum to give 2a-b. [8] Under dry $\mathrm{N}_{2}$ atmosphere, DCC ( $1.1 \mathrm{mmol}, 0.22 \mathrm{~g}$ ), DMAP (0.3 mmol, $0.036 \mathrm{~g}$ ), and $3 \mathrm{a}-\mathrm{b}(0.8 \mathrm{mmol}, 0.1 \mathrm{ml})$ were added to the stirred solution of 2a-b (1 mmol, $0.21 \mathrm{~g})$ dissolved in DCM $(5 \mathrm{ml})$. The reaction mixture was stirred at room temperature for $48 \mathrm{~h}$, and then the solvent was evaporated to half of the volume. The reaction mixture was quenched by the addition of dilute $(0.5 \mathrm{M}) \mathrm{HCl}$ and extracted with ethyl acetate. The organic phase was dried over $\mathrm{Na}_{2} \mathrm{SO}_{4}$. The crude was purified by column chromatography as $4 \mathrm{a}-\mathrm{d}$. To a stirred solution of $4 \mathrm{a}-\mathrm{d}$ ( $1 \mathrm{mmol}, 0.318 \mathrm{~g}$ ) 
dissolved in DCM $(10 \mathrm{ml})$ was added trifluoroacetic acid $(4.3 \mathrm{ml})$ at $0^{\circ} \mathrm{C}$. Slowly, the temperature was warmed to room temperature and stirring was continued for $5 \mathrm{~h}$. [9] Then, the solvent was evaporated and neutralized with $10 \% \mathrm{NaOH}$ aqueous solution. Ethyl acetate was added to extract the product. The organic phase was dried over $\mathrm{Na}_{2} \mathrm{SO}_{4}$. The crude was purified by column chromatography to get the product, 5a-d as brown colored liquid. All the four prolinamide ligands were confirmed by ${ }^{1} \mathrm{H}$ and nuclear magnetic resonance $\left({ }^{13} \mathrm{C} N \mathrm{NR}\right)$ analysis.

\section{Ligand preparation for molecular docking}

Chemical structures of ligands (L-Proline, D-Proline, $\mathrm{D}[S, R]$ prolinamide and $L[S, R]$ prolinamide) were drawn in ChemBioDraw Ultra 12.0 and energy minimization of ligands was carried out by ChemBio threedimensional (3D) Ultra 12.0, according to the reported procedure [10]. These structures were employed for further PatchDock.

\section{Target protein identification and preparation}

The 3D structures of the Clostridium histolyticum collagenase (Protein Data Bank [PDB] ID: 4ARE with resolution of 2.19 A) were obtained from the Research Collaboratory for Structural Bioinformatics PDB (www.rcsb.org). A chain of the protein was processed individually by removing another chain, ligands in addition to the crystallographically observed water particles (water without hydrogen bonds). The protein mentioned above was prepared using UCSF Chimera software [11].

\section{Molecular descriptors calculation}

Molinspiration online database was used for the two selected ligands to calculate 13 descriptors (www.molinspiration.com) which are logP, polar surface area, molecular weight, number of atoms, number of $\mathrm{O}$ or $\mathrm{N}$, number of $\mathrm{OH}$ or $\mathrm{NH}$, number of rotatable bond, and drug-likeness including $\mathrm{G}$ protein-coupled receptors ligand, ion channel modulator, kinase inhibitor, nuclear receptor ligand, and number of violations to Lipinski's rule [12]

\section{ADME analysis}

ADME analysis was performed by Swiss ADME analysis was carried by a standard default protocol [13].

\section{Docking studies}

Docking studies were carried out by the PatchDock online server (http://bioinfo3d.cs.tau.ac.il/PatchDock). PatchDock adopts geometry-based molecular docking algorithm method was used to recognize the binding scores, by binding residues atomic contact energy (ACE) of the given ligands. The docking results were obtained through the email address. We also use to get uniform resource locator which provides the top 20 solutions in a table form through email. From these, the top one solution (the docked protein-ligand complex) was selected and downloaded in a database (pdb) file format. Further, the binding site analysis was carried out by PyMOL software [14].

\section{RESULTS AND DISCUSSION}

In the present study, proline (L-Proline, D-Proline) and prolinamide (D $[S, R]$ prolinamide and $\mathrm{L}[S, R]$ prolinamide) isomers have been synthesis and selected to evaluate as bacterial collagenase inhibitory activity using in silico method. All the four prolinamide isomers (Scheme 1; 5a-5d) were confirmed by Proton $\left({ }^{1} \mathrm{H}\right)$ and Carbon $\left({ }^{13} \mathrm{C}\right.$ ) NMR analysis and results were shown below.

\section{LR-prolinamide (5a)}

Yield: 97\%; ${ }^{1} \mathrm{H}$ NMR: $\left(400 \mathrm{MHz}, \mathrm{CDCl}_{3}\right) \delta(\mathrm{ppm}): 8.13(1 \mathrm{H}, \mathrm{d}, J=16 \mathrm{~Hz})$, $7.22(5 \mathrm{H}, \mathrm{s}), 5.04-4.89(1 \mathrm{H}, \mathrm{m}), 3.87-3.78(1 \mathrm{H}, \mathrm{m}), 3.01-2.82(2 \mathrm{H}, \mathrm{m})$, 2.14-1.99 (1H, m), 1.85-1.56 (4H, m), $1.34(3 \mathrm{H}, \mathrm{d}, J=12 \mathrm{~Hz}),{ }^{13} \mathrm{C}$ NMR: $\left(100 \mathrm{MHz}, \mathrm{CDCl}_{3}\right) \delta(\mathrm{ppm}): 172.6,143.5,128.3,126.0,125.7,60.1,48.2$, $46.8,30.4,25.5,22.1$.

\section{LS-prolinamide (5b)}

Yield: 93\%; ${ }^{1} \mathrm{H}$ NMR: $\left(400 \mathrm{MHz}, \mathrm{CDCl}_{3}\right) \delta(\mathrm{ppm}): 8.72(1 \mathrm{H}, \mathrm{d}$, $J=7.2 \mathrm{~Hz}), 7.23-7.13(5 \mathrm{H}, \mathrm{m}), 4.84-4.81(1 \mathrm{H}, \mathrm{m}), 4.52(1 \mathrm{H}, \mathrm{t}, J=8 \mathrm{~Hz})$, 3.15-3.10 (2H, m), 2.30-2.26 (1H, m), 1.83-1.68 (4H, m), $1.34(3 \mathrm{H}, \mathrm{d}$, $J=8 \mathrm{~Hz}),{ }^{13} \mathrm{C} \mathrm{NMR:}\left(100 \mathrm{MHz}, \mathrm{CDCl}_{3}\right) \delta(\mathrm{ppm}): 167.9,143.4,128.6,127.2$, $125.6,59.5,50.2,46.3,30.0,24.4,22.0$.

\section{DR-prolinamide (5c)}

Yield: 91\%; ${ }^{1} \mathrm{H}$ NMR: (400 MHz, $\left.\mathrm{CDCl}_{3}\right) \delta(\mathrm{ppm}): 8.69(1 \mathrm{H}, \mathrm{d}$, $J=8 \mathrm{~Hz}), 7.22-7.14(5 \mathrm{H}, \mathrm{m}), 4.86-4.82(1 \mathrm{H}, \mathrm{m}), 4.50(1 \mathrm{H}, \mathrm{t}, J=8 \mathrm{~Hz})$, $3.16-3.12(2 \mathrm{H}, \mathrm{m}), 2.29(1 \mathrm{H}, \mathrm{d}, J=8 \mathrm{~Hz}), 1.82-1.75(4 \mathrm{H}, \mathrm{m}), 1.35(3 \mathrm{H}, \mathrm{d}$, $J=8 \mathrm{~Hz}) ;{ }^{13} \mathrm{C}$ NMR: $\left(100 \mathrm{MHz}, \mathrm{CDCl}_{3}\right) \delta(\mathrm{ppm}): 168.1,143.4,128.6,127.2$, $125.6,59.5,50.1,46.3,30.1,24.4,22.1$

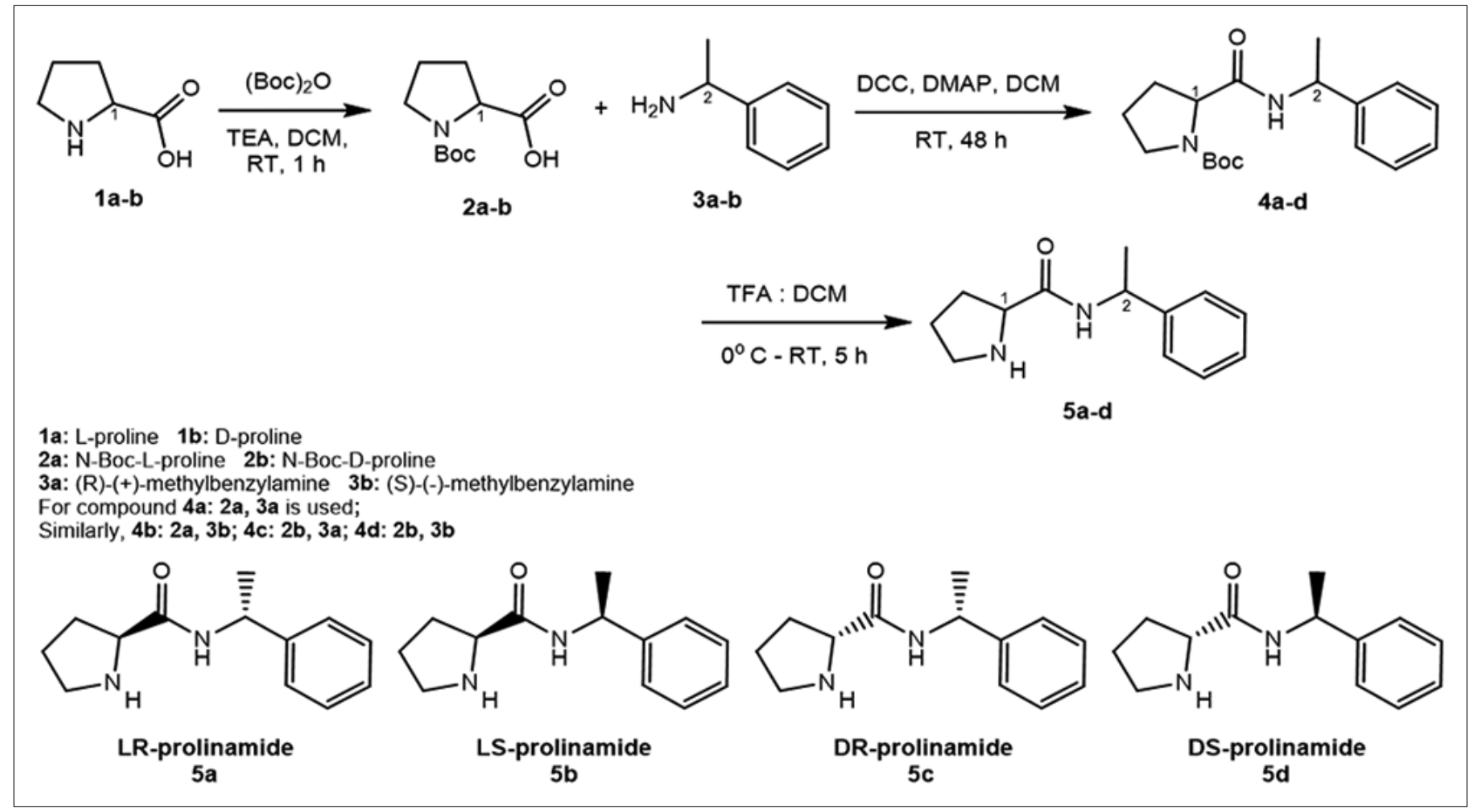

Scheme 1: Synthesis of prolinamide isomers 
Table 1: Molecular physicochemical descriptors analysis of proline and prolinamide isomers using Molinspiration online software tool

\begin{tabular}{|c|c|c|c|c|c|c|c|c|c|}
\hline Ligand names & $\log A^{a}$ & TPSA $^{\text {b }}$ & Natoms $^{c}$ & $\mathbf{M W}^{\mathrm{d}}$ & $\mathrm{nON}^{\mathrm{e}}$ & nOHNH $^{\mathrm{f}}$ & Nviolations $^{g}$ & Nrotb $^{h}$ & Volume $^{\mathrm{i}}$ \\
\hline LS & 1.55 & 41.12 & 16 & 218.30 & 3 & 2 & 0 & 3 & 217.61 \\
\hline LR & 1.55 & 41.12 & 16 & 218.30 & 3 & 2 & 0 & 3 & 217.61 \\
\hline DS & 1.55 & 41.12 & 16 & 218.30 & 3 & 2 & 0 & 3 & 217.61 \\
\hline DR & 1.55 & 41.12 & 16 & 218.30 & 3 & 2 & 0 & 3 & 217.61 \\
\hline L-proline & -1.72 & 49.33 & 8 & 115.13 & 3 & 2 & 0 & 1 & 108.43 \\
\hline D-proline & -1.72 & 49.33 & 8 & 115.13 & 3 & 2 & 0 & 1 & 108.43 \\
\hline
\end{tabular}

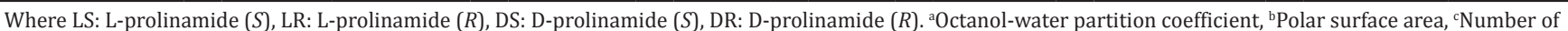
non-hydrogen atoms, ${ }^{\mathrm{d}}$ Molecular weight, ${ }^{\mathrm{e}} \mathrm{Number}$ of hydrogen bond acceptors ( $\mathrm{O}$ and $\mathrm{N}$ atoms), ${ }^{\mathrm{f}} \mathrm{Number}$ of hydrogen bond donors ( $\mathrm{OH}$ and $\mathrm{NH}$ groups), ${ }^{\mathrm{g}} \mathrm{Number}$ of

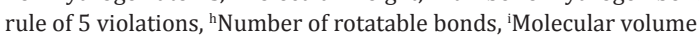

Table 2: Drug-likeness property analysis of proline and prolinamide isomers using Molinspiration online software tool

\begin{tabular}{llllll}
\hline $\begin{array}{l}\text { Ligand } \\
\text { names }\end{array}$ & $\begin{array}{l}\text { GPCR* } \\
\text { ligand }\end{array}$ & $\begin{array}{l}\text { Ion channel } \\
\text { modulator }\end{array}$ & $\begin{array}{l}\text { Kinase } \\
\text { inhibitor }\end{array}$ & $\begin{array}{l}\text { Nuclear receptor } \\
\text { ligand }\end{array}$ & $\begin{array}{l}\text { Enzyme } \\
\text { inhibitor }\end{array}$ \\
\hline LS & -0.01 & 0.16 & -0.39 & -0.82 & 0.21 \\
LR & -0.01 & 0.16 & -0.39 & -0.82 & -0.10 \\
DS & -0.01 & 0.16 & -0.39 & -0.82 & -0.10 \\
DR & -0.01 & 0.16 & -0.39 & -0.82 & -0.10 \\
L-proline & -2.15 & -1.54 & -3.08 & -3.07 & -1.72 \\
D-proline & -2.15 & -1.54 & -3.08 & -3.07 & -1.85 \\
\hline
\end{tabular}

*GPCR: G protein-coupled receptors. Where LS: L-prolinamide (S), LR: L-prolinamide (R), DS: D-prolinamide (S), DR: D-prolinamide (R)

Table 3: ADME analysis of proline and prolinamide isomers using Swiss ADME online software tool

\begin{tabular}{|c|c|c|c|c|c|c|c|c|c|}
\hline Ligand names & $\mathbf{G I}^{\bullet}$ & BBB $^{\#}$ & P-gp & CYP1A2* & CYP2C19* & CYP2C9* & CYP2D6* & CYP3A4* & $\log K_{p}^{0}$ \\
\hline LS & High & Yes & No & No & No & No & No & No & -7.26 \\
\hline LR & High & Yes & No & No & No & No & No & No & -7.26 \\
\hline DS & High & Yes & No & No & No & No & No & No & -7.26 \\
\hline DR & High & Yes & No & No & No & No & No & No & -7.26 \\
\hline L-proline & High & No & No & No & No & No & No & No & -8.78 \\
\hline D-proline & High & Yes & No & No & No & No & No & No & -8.78 \\
\hline
\end{tabular}

•Gastrointestinal absorption, "blood-brain barrier permanent, ${ }^{\circ P}$-gp: P-glycoprotein substrate, ${ }^{*} \mathrm{CYP}$ : Cytochrome P450 inhibitors, ${ }^{\ominus}$ Skin permeation (cm/s). Where

LS: L-prolinamide (S), LR: L-prolinamide (R), DS: D-prolinamide (S), DR: D-prolinamide $(R)$. ADME: Absorption, distribution, metabolism, and excretion

\section{DS-prolinamide (5d)}

Yield: 95\%; ${ }^{1} \mathrm{H}$ NMR: $\left(400 \mathrm{MHz}, \mathrm{CDCl}_{3}\right) \delta(\mathrm{ppm}): 8.39(1 \mathrm{H}, \mathrm{d}, J=16 \mathrm{~Hz})$, $7.29(5 \mathrm{H}, \mathrm{s}), 5.00(1 \mathrm{H}, \mathrm{t}, J=16 \mathrm{~Hz}), 4.56(2 \mathrm{H}, \mathrm{s}), 4.07-4.00(1 \mathrm{H}, \mathrm{m})$, 3.07-2.96 (1H, m), 2.31-2.15 (1H, m), 1.89-1.70 (3H, m), $1.47(3 \mathrm{H}, \mathrm{d}$, $J=12 \mathrm{~Hz}) ;{ }^{13} \mathrm{C}$ NMR: $\left(100 \mathrm{MHz}, \mathrm{CDCl}_{3}\right) \delta(\mathrm{ppm}): 171.7,143.5,128.4$, $126.0,125.9,60.1,48.6,46.8,30.5,25.3,22.2$.

The molecular formula of Proline is $\mathrm{C}_{5} \mathrm{H}_{9} \mathrm{NO}_{2}$. The International Nomenclature of Cosmetic Ingredients name is proline. Proline is an amino acid containing pyrrole type nitrogen. The unique cyclic structure of proline (side chain) gives proline an exceptional conformational rigidity compared to other amino acids. It is one of the two amino acids (along with glycine) that do not follow the typical Ramachandran plot. Proline is used in skin care and hair care products and cleansers [5]. Similarly, proline analogs and homologs have reported to possess cosmetic applications [6,7]. Matrix metalloproteinases (MMPs) plays a key role in the various physiological process (angiogenesis, wound healing) and pathological process (photo-aging [15], inflammation, and metastasis). Therefore, design and development of MMP inhibitors have promoted significant interest among the scientist [16].

It could be beneficial to know the physiochemical, drug-likeness and ADME properties of proline and prolinamide isomers before carry out docking studies. The molecular physicochemical analysis revealed that proline and prolinamide isomers showed nil violation and complied well with the Lipinski's rule of five (as shown in Table 1).

With regard to drug-likeness score, if the score $>0$ is active, $-5.0--0.0$ is moderate active, and $<-5.0$ is inactive [17]. The ligands (prolinamide isomers) showed active score toward two descriptions (ion channel
Table 4: The interaction energy analysis of proline and prolinamide isomers with that of $C$. histolyticum collagenase using PatchDock

\begin{tabular}{llll}
\hline Ligand & $\begin{array}{l}\text {-ACE } \\
\text { (kcal/mol) }\end{array}$ & $\begin{array}{l}\text { Interaction of } \\
\text { amino acid residue }\end{array}$ & $\begin{array}{l}\text { Bond } \\
\text { distance (Å) }\end{array}$ \\
\hline LS & +24.10 & Gln 710 & 3.51 \\
LR & +24.10 & Gln 710 & 3.51 \\
DS & 115.09 & Asn 210 & 2.87 \\
DR & 115.09 & Asn 210 & 2.87 \\
L-proline & 43.04 & Tyr 528 Thr 421 & 1.7 and 2.9 2.4 \\
D-proline & 69.14 & Tyr 724 & 2.5 \\
\hline
\end{tabular}

${ }^{\circ}$ atomic contact energy, where LS: L-prolinamide $(S)$, LR: L-prolinamide $(R)$,

DS: D-prolinamide (S), DR: D-prolinamide $(R), C$. histolyticum: Clostridium histolyticum

modulator and protease inhibitor). Interestingly, none of them showed inactive score as shown in Table 2.

ADME analysis showed that all the ligands (except L-proline) predicated to have blood-brain barrier permeability effect (Table 3).

The anti-collagenase activity of several natural/synthetic products has been evaluated using $C$. histolyticum collagenase as biomarker, and its inhibitors have been developed for treating bacterial corneal keratitis disease [11]. Present docking studies revealed that $\mathrm{D}(S, R)$ prolinamide isomer showed the maximum ACE $(-115.09 \mathrm{kcal} / \mathrm{mol})$ with that of $C$. histolyticum collagenase (as shown in Table 4), while L $(S, R)$ prolinamide isomer showed poor binding phenomenon as reported by Akdogan et al. [18]. 
The present finding was in good agreement with the earlier report, where author's developed pyrrolidine scaffold based MMP inhibitors [19]. In the present study, interaction with Asn 210 amino acid residue has been shown by $\mathrm{D}(S, R)$ prolinamide isomer (Table 4). The present finding was in good agreement with an earlier report [11].

\section{CONCLUSION}

In the present study, D $(S, R)$ prolinamide isomer and D-proline exhibited high ACE value, when compared to $\mathrm{L}(S, R)$ prolinamide isomer and L-proline. Thus, the present study showed the potential of proline (Pyrrolidine 2-carboxylic acid) and prolinamide (Pyrrolidine 2-carboxylic acid amide) isomers as bacterial collagenase inhibitors.

\section{ACKNOWLEDGMENT}

The authors express their sincere gratitude to the authority of Vel Tech Rangarajan Dr. Sagunthala R and D Institute of Science and Technology, Avadi, Chennai, for their constant support.

\section{AUTHOR'S CONTRIBUTIONS}

KS (first author), who had wrote the manuscript and submitted the same. Other two authors have added value to it. All authors read and approved the final manuscript.

\section{CONFLICTS OF INTEREST}

The authors have declared no conflicts of interest.

\section{REFERENCES}

1. Nagata Y, Masui R, Akino T. The presence of free D-serine, D-alanine and D-proline in human plasma. Experientia 1992;48:986-8

2. Nagata $Y$, Higashi M, Ishii $Y$, Sano $H$, Tanigawa M, Nagata K, et al. The presence of high concentrations of free $\mathrm{D}$-amino acids in human saliva. Life Sci 2006;78:1677-81

3. Gupta SK, Mandal P. Bioinformatics characterization of SOD under UV in fenugreek (Family: Fabaceae). Int J Pharm Pharm Sci 2016;8:231-7.

4. Wagner I, Musso H. New naturally occurring amino acids. Angew Chem Int Ed Engl 1983;22:816-28.

5. Burnett CL, Heldreth B, Bergfeld WF, Belsito DV, Hill RA, Klaassen CD, et al. Safety assessment of $\alpha$-amino acids as used in cosmetics. Int J Toxicol 2013;32:41S-64.

6. Haraya N, Oshimura E. Moisturizer and Cosmetic Containing Same.
Patent 9782336. US: Ajinomoto Co., Inc.; 2017.

7. Roso A, Garcia C. Cosmetic and Pharmaceutical Compositions Comprising Lauroyl Proline and an Ester of Anhydrohexitol and of an Aliphatic Carboxylic Acid. Patent 8093221. US; 2012.

8. Wu X, He C, Wu X, Qu S, Duan C. An L-proline functionalized metalloorganic triangle as size-selective homogeneous catalyst for asymmetry catalyzing aldol reactions. Chem Commun (Camb) 2011;47:8415-7.

9. Jiangwei X, Xiangkai F, Chuanlong W, Xiaoyan H. Simple, inexpensive, and facile L-prolinamide used as a recyclable organocatalyst for highly efficient large-scale asymmetric direct aldol reactions. Tetrahedron Asymmetry 2011;22:840-50.

10. Vijayakumar V, Radhakrishnan N, Rameshkumar C. Molecular Docking Analysis of Imidazole Derivatives and Polybenzimidazole Analogues as Inhibitors of Superoxide Dismutase (SOD) and Xanthine Oxidase (XO). IEEE International Conference on Smart Technologies and Management for Computing, Communication, Controls, Energy and Materials (ICSTM); 2017. p. 513-6.

11. Radhakrishnan N. Molecular docking analysis of alginate oligosaccharides (Alg2-Alg6) as bacterial collagenase inhibitor. J Appl Cosmetol 2017;35:15-23.

12. Radhakrishnan N, Lam KW, Faridah A, Intan IS. Molecular docking analysis of curcumin analogues elastase (HNE) inhibitors. Bangladesh J Pharm 2014;9:77-82.

13. Daina A, Michielin O, Zoete V. SwissADME: A free web tool to evaluate pharmacokinetics, drug-likeness and medicinal chemistry friendliness of small molecules. Sci Rep 2017;7:42717.

14. Schneidman-Duhovny D, Inbar Y, Nussinov R, Wolfson HJ. PatchDock and SymmDock: Servers for rigid and symmetric docking. Nucleic Acids Res 2005;33:W363-7.

15. Rojas J, Londono C, Ciro Y. The health benefits of natural skin UVA photoprotective compounds found in botanical sources. Int J Pharm Pharm Sci 2016;8:13-23

16. Radhakrishnan N, Lam KW, Intan IS. In silico analysis of selected honey constituents as human neutrophil elastase (HNE) and matrix metalloproteinases (MMP 2 and 9) inhibitors. Int J Food Prop 2015;18:2155-64.

17. Singh S, Gupta AK, Verma A. Molecular properties and bioactivity score of the Aloe vera antioxidant compounds - In order to lead finding. Res J Pharm Biol Chem Sci 2013;4:876-91.

18. Akdogan ED, Erman B, Yelekci K. In silico design of novel and highly selective lysine-specific histone demethylase inhibitors. Turk J Chem 2011;35:523-42

19. Cheng XC, Wang Q, Fang $\mathrm{H}$, Xu WF. Advances in matrix metalloproteinase inhibitors based on pyrrolidine scaffold. Curr Med Chem 2008;15:374-85. 